\title{
WHY THE DELIBERATIVE IDEAL JUSTIFIES PUBLICITY - EVEN IF PUBLICITY MAY UNDERMINE DELIBERATION
}

\section{POR QUE O IDEAL DELIBERATIVO JUSTIFICA A PUBLICIDADE - AINDA QUE A PUBLICIDADE POSSA COMPROMETER A DELIBERAÇÃO}

\author{
John Pitseys* \\ john.pitseys@uclouvain.be
}

\begin{abstract}
This paper critical assesses those arguments in democratic theory which defend the role of secrecy in politics in epistemic terms, that is, by emphasizing some of the negative effects that publicity in deliberation can have (namely: obscuring the informational process, favoring plebiscitory rhetorics, and replacing open discussion with conformist behaviors and/or bargaining). Based upon the analysis of the 2010-2011 Belgian Sixth State Reform, the paper argues that, even if publicity can produce negative effects on deliberation, it cannot be proven that these effects are more severe than those produced by a closed-doors deliberation. Furthermore, it argues that an epistemic justification of closed-door deliberation could not be accepted by a reasonable citizen: the justification of publicity does not rely on its epistemic positive effects, but on the fact that the assessment and definition of these cannot be left to the negotiating parties.
\end{abstract}

Keywords: political publicity, political secrecy, public deliberation.

Sumário. Este artigo avalia, criticamente, os argumentos que, na teoria política, defendem, por razões epistémicas, o papel do secretismo na política. Desta maneira, enfatizamos alguns dos efeitos negativos que a publicidade pode ter na deliberação (designadamente: obscurecendo o processo informacional, favorecendo retóricas plebiscitárias e substituindo a discussão aberta por comportamentos conformistas e/ ou barganha). Com base na análise da Sexta Reforma do Estado Belga de 2010-2011, este artigo defende que embora a publicidade possa produzir efeitos negativos na deliberação, não se pode provar que estes efeitos são mais severos do que aqueles produzidos por uma deliberação à porta fechada. Além disso, argumentamos que uma justificação epistémica da deliberação à porta fechada não poderia ser aceite por um cidadão razoável: a justificação da publicidade não depende dos seus efeitos epistémicos positivos mas sim do facto de a avaliação e definição destes não poder ser deixada ao critério das partes em negociação. 
Palavras-chave: publicidade política, secretismo político, deliberação pública.

Democratic theory links political legitimacy to two possible sorts of criteria. First, the political decision must reflect on an equal basis the interests expressed by the social space. Second, the political decision must reflect the common good, which relies upon a rational decision-making process. These two conceptions are subject to contention but converge on the point that publicity is a political virtue that must necessarily be pursued and which is descriptively and normatively opposed to secrecy and lying.

A closer look at the notion of political publicity reveals however a number of difficulties. Publicity can hinder the conditions of rational collective deliberation. Reversely, meeting the conditions of a rational collective deliberation may lead to restricting the exercise of political transparency. Deliberation is supposed to favor an inclusive dialogue between the members of the citizenry. However, there can be some strong divergences on the extent to which the decision-process must be open to citizens, and - consequently - on the nature of the justifying base of a deliberative system.

Political publicity seems thus both a central democratic principle and a mined field for philosophical dilemmas: in this context, to what extent can a closed-door deliberation be legitimate in the framework of a political decision? Must the decision making process be open if it can be proven that it harms the epistemic quality of the deliberation, and thus the average level of fairness of the content of the decision?

I do not deny that publicity can harm the overall quality of political deliberation. I think nevertheless that there is no reason to restrain publicity in the name of public reason. I am not saying that there are no valid normative grounds to limit publicity, and the conclusion of the paper suggests political equality might be the best yardstick on which to base an option for public or closed-door deliberation. But I think that the deliberative argument against publicity is weak in this regard.

In order to structure my point, I will first remind the reasons why publicity can harm the deliberative quality of the political discussion. Here I do not aim 
however to show that the practical conditions for public discussion do not match the deliberative ideal - which would be a trivial assertion. Nor will I recall that deliberation and democracy fall under practically and analytically distinct categories. Rather, this paper aims to show that the best way to approach the conditions of a rational deliberation might require restraining political publicity and, reversely, that the arguments against publicity might actually fit with a nonideal understanding of the deliberative ideal.

The second part of the paper suggests that the possible negative epistemic effects of publicity do not suffice to justify secrecy. From a consequentialist view, I develop the idea that the epistemic arguments against secrecy can all be replicated in the context of a closed-door deliberation. And from an internal normative aspect, I try to demonstrate that the deliberative argument against publicity is not consistent with the normative basis it ought to stand for. Should closed-door deliberation promote the quality of the discussion and respect citizen's political rights, it contravenes the egalitarian understanding of impartiality deliberative democracy is expected to be grounded on. In this framework, the conclusion of the paper suggests that if secrecy must be rejected when it disregards impartiality, it could be justified if and when it respects this principle.

Finally, the reader will notice that this paper finds a major inspiration from my practical experience as a political adviser during the Belgian sixth State Reform negotiation process that took place between June 2010 and December 2011 - and broke the record for the longest formation of a government. This period was a testing experience. It gave, I think, a rare source of reflection for understanding the complex relationship between representative and deliberative legitimacy, and between ideal and non-ideal theories of legitimacy.

\section{Deliberation and Publicity}

\subsection{Three conceptions of publicity}

Three conceptions of publicity may be distinguished in political theory. First, publicity can be understood as the principle of public information (A). Citizens are informed of the practices, arguments and decisions that take place within the political system: publicity designates the process by which political 
facts are presented and made available to the public (Gutmann, Thompson, 1999, chap. III). Such a process relates to the access to political information, that is to say the content of the norms that apply to the collectivity, the arguments and positions of the parties, the justification process of the decision (Rawls, 1993: 6667). It designates also the ownership modalities of the information.

A second conception understands publicity as a collective background for the justification of public discussion (B). This background encompasses the public information onto itself but also the substrate of its collective treatment, that is to say a common space of political understanding and justification (Luban, 1996, pp. 171-172; Manin, 1996, pp. 215-216). In this framework, the conception $\mathrm{B}$ both describes and justifies the conditions for the constitution of the public debate. It includes the legal procedures of public disclosure as well as the general access to the content of the political discussion. But most of all it encompasses various institutions that are to cover political information, organize the collective discussion and civilize the citizen's behaviours: we think here about the informational networks of the civil society, the action of the mass media, the conversations within informal public sphere, etc. The conception B covers both the access to the information and to the public space, and what makes possible the discussion about them.

These two conceptions respond to a practical ideal, as the social and political institutions must meet effectively their requirement of justification. This ideal serves two different possible functions. First, it represents an ideal of public discussion, insofar as the principle of publicity is supposed to enhance the volume, the quality and the responsiveness of the arguments put on the table of the political discussion. Second, it serves an ideal of democratic participation. On the one hand the constitution of a public sphere of information is supposed to connect the exercise of the government with popular sovereignty: the political publicity constitutes both a means of control of the represented on the representatives, and a way for the representative to have access to the issues, perspectives, perceived interests and political pulse of the represented. On the other hand, the principle of publicity contributes to the creation of a common general public space. 
Finally, publicity can also be understood as a hypothetical way to test the rightness of the decision (C) (Bohman, 1996, p. 25). The conceptions A and B see publicity as a benchmark to organize the public space and the actual conditions of the political debate. The conception $\mathrm{C}$ approaches the meaning of the transcendental principle of publicity as defined by Kant in his Treaty on Perpetual peace: "All actions relating to the right of other human beings are wrong if their maxim is incompatible with publicity" (Kant, 1795, p. 130). According to Kant, a policy "which cannot be publicly acknowledged without thereby inevitably arousing the resistance of everyone to my plans, can only have stirred up this necessary and general (hence a priori foreseeable) opposition against me because it is itself unjust and thus constitutes a threat to everyone" (Ibidem: 126). Being hypothetical, such a test doesn't entail any real public but only the putative unveiling of the argument (Ibid.: 131). In the words of Axel Gosseries, "the test is thus hypothetical, not only because it does not necessarily require actual publicity (as we shall see), but also because any outcome of actual publicity would inevitably remain at best a rough approximation of what the test would lead us to with an ideal public" (Gosseries, 2005). Following this acceptation, the principle of publicity does not compel the political actor to communicate his reasons to the other parties. Nonetheless he has to universalize these reasons assessing whether they can be accepted by all. A reason which is valid for me cannot be accepted unless it is valid for the others as well: an action which does not pass the test of the universal audience cannot be considered and, consequently, has to be rejected.

In this context, there is to be a converging relationship between the three mentioned definitions of publicity: "The best way to make sure that officials formulate policies that could withstand publicity is by increasing the likelihood that policies will withstand publicity" (Luban, 1996, p. 157). More information is more contextual justification. And more contextual justification paves the way for a higher level of generality.

\subsection{The Three Classical Critiques to publicity and The Deliberative Ideal}


Political publicity faces three classical critiques. The first one is related to the argument for the Reason of State, that is to say the title by which the State can use discretionary powers in order to preserve the existence of the community and protect it from its enemies within and outside. If all political information is available to the public, it means it is also available for these enemies: the information strategically related to the subsistence and vital interests of the community must thus stay concealed. The argument of the Reason of State is not intrinsically linked to a state of emergency but to the identification of two distinct spheres: the sphere of war, according to which a political collectivity has for primary purpose the pursuit of its own continuity; and the political sphere, according to which a political collectivity has for fundamental ideal the pursuit of the common good of its constituency. These two spheres are analytically distinct but their issues, arguments and involved actors are entangled so that it is impossible to prevent the circulation of information from reaching enemy hands without blocking its access to the citizenry.

The second one is the elitist argument, according to which the principle of publicity can be useless, and even counterproductive in the framework of a pluralist and liberal democracy. As a consequence of the social division of labor, the main part of the citizenry is not competent to judge the way political representatives handle public affairs. Moreover, citizens are for the most part not willing to participate in public life, whether it be because they are uninterested or because they lack the time to dedicate themselves to the ruling of public affairs. In this context, a democratic regime has to ensure that the general tenets of the formal political discussion are accessible to the public and that the laws, their application and their adjudication be properly publicized, but the political space cannot be held responsible for the lack of information and/or political expertise of the general public space.

The third one is related to the dilemma of the plain political information, which can be summarized through the following sentence: the political information can be clear or complete but not both, and certainly not neutral. Either we assume that the principle of publicity requires translating the political information into a clear and accessible content. In that case, such mediated public information stems from a cognitive selection process. In what conditions 
is this process handled? Who is the actor taking charge of the selection of the information? The ideal of plain, clear information unavoidably raises the questions of the possible biases accompanying the selection process, and the power asymmetries which at the same time cause and arise from it. The other option is to assume that providing the citizen with complete political information is an attainable goal. Various studies and experiments tend to show that complete information can paradoxically harm the level of collective understanding. First, the profusion of public information makes it more difficult to find the accurate input. The apparent "neutrality" of the information reinforces paradoxically its opacity for the citizen. ${ }^{1}$ The total and overabundant disclosure of information can even be used to dissimulate information that the authority would prefer to be kept discrete. Second, complete information might stay undecipherable for most of the members of the community, and especially those who suffer from social and educational inequalities. The technicality of the laws and administrative regulations feeds the already existing gap between the most and least resourceful and/or specialized actors. Third, pure information doesn't entail a clear and transparent reception of its content. The communication is a process by which not only the sender but also the receiver of the message contributes to color the content and the meaning of the message. Various experiments in social psychology show for instance that, when confronted with uncommented information, people tend to give more attention to the unexpected, emotional, negative (Rottenstreich, Hsee, 2001; Hsee, Hastie, 2006), loss-related (Tversky, Kahneman, 1991), more accessible or striking (Wilson, 2002) information despite the objective relevance of this information.

These three arguments can be taken as purely factual: but they also have a normative dimension, since they assume the factual features of the public give a solid normative ground for limiting publicity. Abundantly discussed in democratic theory, the deliberative ideal seems to offer a convincing answer to these three classical critiques of political publicity.

The deliberative ideal derives the legitimacy of a political decision from the deliberation between free and equals parties leading to a rationally justified

1 "Consider for example, public knowledge and public opinion during the period prior to the invasion of Iraq in 2003. Long after sufficient information existed to disprove the contention, large segments of the American believed (...) in a proved link between Saddam Hussein and al Qaeda" (Fenster, 2006: 929) 
consensus (Cohen, 1986, 1989, 1996; Elster, 1986; Habermas, 1992). It relies thus upon two conditions: a condition of collective participation and a condition of argumentation. The condition of participation means that the discussion is open to all members of the political community. It has to allow them to express themselves in an autonomous way. The deliberative model proposes a fair, inclusive and discursive procedure "to which all the citizens may participate and by which they are brought to a fair cooperation" (Blondiaux, Sintomer, 2002, p. 18). The condition of argumentation stipulates that the general interest does not result from a transcendent principle or the sum of the interests/preferences of the citizens, but from the formative process of a collective agreement dictated by the rule of the best argument.

In this context, deliberation can be first conceived through its capacity to attain the conditions of a fair procedure (I) (Christiano, 1996). A good deliberation gives everybody an equal/fair say. It supposes that the citizens be granted equal political rights and equal opportunities to participate in the decision-making process. To this end, the epistemic quality of the discussion is seen as a tool to clarify the different interests involved, the stakes of the discussion, the rules and narratives of the discussion. Deliberation can be defined as well through its capacity to contribute to the epistemic quality of the discussion (II) (see Estlund, 2009). The definition of a rational decision is neither given nor defined by the deliberative process. The deliberative process provides the discursive tools for approaching the conditions of a rational decision. The best arrangement for approaching the independent criterion of a reasonable decision is thus the democratic deliberation. For the classical version of the epistemic model, political deliberation promotes a balanced dialogue, a reasoned exchange of reasons, or a mutual amendments process (II.1). And for the extended version of the epistemic model, deliberation helps to clarify the parties' preconceptions, and to encourage a collective recognition of the different collective identities involved. Finally, political deliberation can be defined as the recognition criteria of a rational decision-making process (III) (see Habermas, 1981 and 1992; Cohen, 1989 and 1996). A true deliberation defines what a rational decisionmaking process is: the ideal conditions of a true deliberation do not only provide a way to assess the quality of the decision but also its correctness. The political deliberation must approach the conditions of the ideal deliberation, which 
determines the conditions for a fair and/or rational result. Habermas', Cohen's or Benhabib's accounts of public deliberation not only give an account of the public reason but a standard of rationality.

In this framework, the deliberative conception of political legitimacy strictly frames the epistocratic or decisionist arguments underlying the principle of the Reason of the State, as public deliberation is supposed to contribute to the collective definition and control of the sphere of secrecy. Considering the conceptions I and II of the deliberation, the Reason of State is no longer - and cannot be - defined by the mere fait du prince. Public deliberation either justifies why the decision must be made public, or the conditions under which it can be concealed from the public's eyes. In this framework, even the decision by which a sphere of secrecy is allowed in some determined cases should ideally be subject to a collective deliberation, before or after creating such a sphere: the question remains open whether the reasons for disclosing or concealing information require having access to its content. The deliberative ideal is not incompatible with the existence of strategic secrecy, but constitutes its hypothetical justification, the practical form by which it is justified, and the channel through which a part of the secret information ends up being disclosed in the public space.

Besides, the deliberative ideal rejects the idea that democracy can be assimilated to the peaceful competitive process by which the political elites could speak and act for the people - in the respect of individual liberties and the rule of law - and assumes that the dilemma of plain political information can be resolved by submitting their content to (the selection and diffusion process of) deliberation. As envisaged here above, political deliberation conceives the common good through the meeting of two conditions: a condition of collective participation and a condition of reasoned argumentation. In this context, the deliberative ideal aims to demonstrate that the incompetence and disinterest of the citizen are not a fatal consequence of the democratic regime. And it assumes that the dilemma of plain political information can be resolved by submitting their content to (the selection and diffusion process of) deliberation.

In this framework, the principle of publicity constitutes both a tool and an objective to achieve with regard to formulating the conditions of argumentation 
and participation. As explained by Mill, publicity both promotes the circulation of true ideas and verifies the relevance of the ones which could be wrong:

\begin{abstract}
the peculiar evil of silencing the expression of an opinion is, that it is a robbing of human race; posterity as well as the existing generation; those who dissent from the opinion, still more than those who hold it. If the opinion is right, they are deprived of the opportunity of exchanging error for truth; if wrong they lose, what is almost as great a benefit, the clearer perception and livelier impression of truth, produced by its collision with error (Mill, 1859, p. 20).
\end{abstract}

Thus, publicity provides the citizen with various tools to have a grasp on the political debate, build up the epistemic capacities of the parties, and foster the collective recognition of the interests (see I). It contributes to the citizen's political maturity (II). It fuels the argumentation process, forces the parties to universalize their reasons, and - finally - show that these reasons are compatible with the general interests (II and III). Assuming that the practical conceptions A and B of political publicity are supportive of the hypothetical conception $\mathrm{C}$, it might even constitute one of the necessary conditions of the narrow conception of deliberation (III). Reversely, a successful deliberation is assumed to increase publicity. The collective deliberation promotes a large circulation of the facts, arguments, views and interests (A). It produces arguments and information (A and $\mathrm{B}$ ), and contributes to the formation of the public space by creating a common discussion substrate (A and B). Finally, the conception II of the deliberation is meant to approach the conditions of hypothetical publicity (C), while the conception III is to give a practical definition of it.

\title{
Second part: Why Transparency Is Not Reasonable for Political
}

\section{Deliberation}

Whatever status is given to the principle of participation, deliberative theorists assume that the creation of deliberative spaces or system contributes to its intensity and quality. Different arguments lead one however to be doubtful about the double converging relationship we described here above, and to envisage the hypothesis according to which a closed-door deliberation might be a better fit, than public debate, for the conditions of a reasoned democratic debate. 
First, a secret deliberation within the political space is not incompatible with the free participation of all in the public debate. Deliberative theories could have been criticized for their underlying elitism and the ambiguity they bear on the status of participation in the deliberative systems: is participation only an instrumental factor of deliberation? What if it can be proven that the participation of all undermines the conditions for a rational collective deliberation? In reality, the publicity of the political space to the general public space is not necessary for a vivid general public space. Even if the tenets of the negotiation remain concealed from the public, the actors of the civil society can still debate about the political programs of the actors involved, their possible strategies or the public policies susceptible of being implemented. Besides, it would be wrong to argue that close-door deliberation would create a technical gap between the expertise of the negotiating/deliberating parties and the members of the public space as a whole, as the members of the public space can of course dispose of expertise on their own. The research centers of the political parties and the organized civil society, the investigative work of the mass media, the specific expertise of the academic environment do give the citizen most of the technical information he needs to take position in the public debate.

Second, and getting back to Luban's sentence, publicity is not necessarily withstood by publicity: closed-door deliberation is not only compatible with the pursuit of the hypothetical conception of publicity (see C), but also the extended practical conception of publicity understood as a background for political justification (B). Better than the public disclosure of the decision-making process, closed-door deliberation is able to support an epistemic deliberative input (II) within the public space and a (more) rational deliberation (II and III) amongst the negotiating parties. Reversely, publicity might harm the quality of the deliberation.

Deliberation relies on a procedural requirement of "sincerity". This requirement of sincerity implies, on the one hand, that the arguments put on the table are ones considered to be true (Habermas, 1983). Whether they are effectively believed or not, they must be defended as such since they are publicly revealed. Should these arguments be put forward as true, that would imply that they are in fact believed to be true, as they are representative of a substantial 
position and can be taken as such by any other reasonable party. On the other hand, the requirement of sincerity does not entail that the public space be provided with a total transparency with regard to personal beliefs, positions and strategies. However, it does require that the arguments set out by one party be true, further calls for other parties to behave the same way, and acceptance that the discussion is ruled by the rule of the best argument. Deliberation does not only encompass a collective recognition of the different available arguments, but also a dynamic of mutual adjustment which seeks to make the general interest prevail over the aggregation of particular interests. Sincerity is here understood as a general principle of deliberative goodwill. Public deliberation does not require sincerity in one's positions only, but also in the way other parties' arguments are treated.

Political publicity supports the first meaning of sincerity at the expense of the second one. First, with transparency the actors could become more reluctant to change their minds and less encouraged to take other points of view into account (Elster, 1998, p. 117; Elster, 1994, p. 249). Publicity forces actors to stay coherent with the reasons they originally gave, and allows them to reduce the cognitive gap potentially existing between the public and their personal beliefs. Nonetheless, the cost of maintaining coherence is high for the deliberative process, as any position change is taken as a lack of (self) coherence. The negotiating parties are more reluctant to stand out from their original stance (Fung, 2003, pp. 348-349). ${ }^{2}$ The public concession of an argument is seen as a defeat for the negotiator for it is perceived as a setback for his political clientele and supporters. And the publicly seen success/influence with regard to an argument is perceived as a victory by the clientele. In this context, being the first to score remains the most accessible way to defend later compromises but also a privileged way to develop pure "plebiscitary” rhetorics (Chambers, 2004).

Second, the political discussion is not a linear process progressively leading toward converging interests, arguments or positions. It is an explorative process, alongside which the parties experiment various negotiative stances, heterodox proposals, hybrid compromises or unpopular second/third-best

2 As demonstrated by MacCoun et Kerr, open voting done by raised hands locks in the positions of the various actors more that secret voting, (Kerr, Mc Coun, 2004). 
outputs. 3 It requires of course taking distance with one's original positions, enduring some argumentative risks, and pushing creativity to its limits (Bok, 1982; Gutmann, Thompson, 1996). Unfortunately, these elements of dialogue tend only to emerge when the actors are guaranteed they won't suffer any prejudices for speaking straightforwardly. As defended in the Seale Case about secrecy surrounding the White House's internal advisory process; presidential advisers will tend to avoid any serious consideration of novel or controversial approaches to presidential problems if they are held publicly accountable for all approaches that were advanced, considered but ultimately rejected.4 In this context, the Frankness and Candor argument assumes that publicity tends to inhibit innovative positions and favor actor's aligning to conformist or authoritarian arguments. 5 Taking the example of the Belgian sixth State Reform in which I had the honor to participate as a political advisor - that left Belgium without any federal government for more than five hundred days between June 2010 and January 2012 - I have described elsewhere that the negotiators could not have reached any common ground without adopting and experimenting with borderline interpretations of the Constitution, informal expert consultancy or crude exchanges on each parties' negotiation interests (Pitseys, 2011). The transformative process underlying the discussion process could not occur without the shared assumption that each submitted proposal goes along with an (in)formal "read and delete" principle.

It can be argued of course that publicity still operates as a filter for the collective decision. Deliberation does not guarantee a correct solution but it permits to neutralize the worst solutions (Evans, Wurster, 1997) and "the more fallacious and superstitious forms of reasoning” (Christiano, 1997, p. 248; see Estlund, 2003, p. 82).

\footnotetext{
3 Thus, closed door deliberation allows to (in French) "explorer toutes les avenues, à l'abri des émois et des pressions de l'opinion, et puissent trouver ... une solution telle que les concessions respectives soient moins onéreuses et leurs gains plus élevés" (Pestiau, 2001, p. 39)

4 Washington D.C. Circuit, Seale Case, F. 3d, 1997, pp. $729-750$ (Fenster, 2006, p. 908).

5 Analyzing the internal governance of various central banks directing boards, Meade and Stasavage showed for instance that the members of these boards express more easily their divergences with the bank director when the meeting is held on behind closeddoors (Meade Stasavage, 2008)
} 
Prolonging this idea, Elster's “civilizing force of hypocrisy” positions itself as a powerful objection to the deliberative defense of closed-door deliberation (Elster, 1998; see also Christiano, 1997, p. 248). According to Elster, publicity compels the citizen to show that his reasons are - even for purely instrumental motives - compatible with the general interest and not only his private or particular interests:

there are certain arguments that simply cannot be stated publicly. In a political debate it is pragmatically impossible to argue that a given solution should be chosen just because it is good for oneself. By the very act of engaging in public debate - by arguing rather than bargaining - one has ruled out the possibility of invoking such reasons (Elster, 1997)

Elster not only shows that the private interests are better defended when they are formulated through a public interest argument, but that public pressure prevents the representatives from setting on the agenda interest-driven arguments (even though these interests are thought to correspond to the common good) to the benefit of general interests arguments. The public political discussion prevents the representatives from putting forward pure opportunistic arguments or partial arguments, but also those normative arguments that do not find common acceptance. Reversely, the publicity of the discussion gives the parties various political and socio-psychological incentives to propose public interest arguments. Furthermore, it would benefit the actor's objectives to truly believe in his line of argumentation - and so reduce his internal cognitive dissonances (Elster, 1995, p. 251; Goodin, 1992, pp. 137-138).

The argument of the "civilizing force of hypocrisy" is not without raising serious questions yet. First, what does "civil" mean? The "civilizing force" argument supposes that the nature of the public interest is uncontroversial, or at least that a social consensus can be found on some fundamental values. But the case for/against political publicity precisely occurs when the political actors have to find an agreement between different perceptions of the common good. A closed-door deliberation is envisaged when the actors have to deal with controversial issues, which spark substantial normative divergences. We could of course counter-object that the original disagreement between the parties is not really caused by divergences about the nature of the public interest, but by disagreements on the consequences it bears or on its practical translation in the political reality. Each party can agree on the fact that "Belgium is worth being 
saved as a unified state" or that "The Belgian sixth State Reform must preserve the fundamental pillars of the social security system", but diverge on what a "unified State" or "fair social security system" is. But in that case, the counterobjection actually gives another reason to dismiss the argument of the "civilizing force”. Even if publicity orients the actors towards public interest arguments and creates a collective notion of common decency, the real reason why the actors negotiate is not linked to the fact they do not share the same public interests concerns, but that they do not understand, interpret and use them in the same way.

Second, what does "civilizing" mean? Simone Chambers shows in "Behind Closed-Doors Deliberation" that the case for/against publicity not only opposes private and public reason arguments, but stages as well a third register of political rationality: the plebiscitary reason. As put forward by Chambers, "speakers still appeal to what they think are common or public values but with a twist, under the 'glare' of publicity these arguments may become shallow, poorly reasoned, or appeal to the worst that we have in common" (Chambers, 2004, p. 394). Manipulation, flattery, pandering or agenda-setting strategies can perfectly be implemented through arguments calling for the common good or the public interest. Finally, even within a civilized public space the idea of a "publicly justifiable" argument does not have any necessary relationship with the idea of deliberation, and more broadly a transformative discussion process. The representatives are still publicly accountable to their electorate and will tend to determine their position according to it (MacCoun, 2006, p. 115). Even a sincere and shared call for common decency can be incompatible with the procedural rule of the best argument. ${ }^{6}$ As a matter of fact, Elster himself acknowledges that public interests arguments are compatible with undebated emotions, conformism, or pure majoritarian rhetoric. There is no reason to think that the rational treatment of the public interests is less controversial than the substantial definition of its nature.

Third, who is the "civilizer"? The argument of the "civilizing force" not only supposes that the general interest can be collectively defined by the general public

6 If the views of the public remain unknown, Lerner and Tetlock show however that the representatives will tend to be more careful in their auto-justification process (See Lerner, Tetlock, « Accounting for the effects of accountability », Psychological Bulletin, vol. 125, $\mathrm{n}^{\circ} 2$, pp. 255-275, in MacCoun, 2006: 115). 
space as a whole, but that such a space practically exists. Belgium - but also ideologically highly-divided liberal countries like the United States (Jamieson, Cappella, 2008; Krebs) - illustrate how various autonomous public spheres can coexist within the same national space, and interact like opaque and independent constituencies (Hahn, 2002). There are both Flemish and French-speaking distinct public opinions, each of them constituted by their own medias, pundits, television channels, informal political networks and civil society. In this framework, the mere notion of public debate is warped from the very start, as taking here some random examples - the very meaning of a "fair compromise" between the two linguistic communities, the historical interpretation of the previous State Reforms or the understanding of the concept of "federalism" do not even find a common political space for these divergences to be discussed. The different fractions of the society do not even confront their disagreements. Each negotiating party can thus defend his own conception of public interest to his own constituency without taking any risk of being contested by the others', further knowing that their (the others') arguments will remain opaque to his own electoral/sociological/linguistic clientele.

Another counter-objection is that the deliberative defense of closed-door deliberation relies on an overly restrictive conception of deliberation. First, deliberative theories have for long extended the notion of deliberation beyond its classical definition as a rationally motivated consensus. Deliberation cannot be reduced to the pursuit of a reasoned argument, or the assessment of the epistemic quality of the discussion within the political space. Understood as fair proceduralism, deliberation aims to free the citizens from the distortions resulting from unequal political power (see I). Understood as a way for approaching an independent criteria of collective rationality, it can be seen (see II.2) also as a tool for raising citizen's sense of civility, favoring the collective recognition of actors (Williams, 1995; Young, 1990), or identifying and clarifying the various actors' positions (Mansbridge, 2006). Second, the epistemic disadvantages of publicity are to be counterbalanced by the advantages it might have for the social deliberative system as a whole, at the level of all the differentiated but interdependent elements which, within society, contribute to tackle political issues through "arguing, demonstrating, expressing and persuading" (Mansbridge et al., 2012, p. 46). The deliberative system designates 
the different levels of power, the institutions and actors composing the deliberative substrate. 7

Unfortunately such a counter-objection is both ambiguous and reversible. If deliberation is ultimately defined through its capacity to define or approach (even minimally) a rational decision, we still have to show that the civilizing or equalizing effect of publicity - as desirable as it may be - has a comparatively more positive (or less negative) effect on the epistemic quality of the decision than a closed-door deliberation. First, the notions of procedural fairness or common civility do not evoke intrinsically any public reason: their relationship is instrumental at best (Estlund, 1997, 2002). Second, the notion of deliberative system:

does not require that every component have a function or that every component be interdependent with every other such that a change in one will automatically bring about a change in all others. If a component does contribute to a function, it is not necessary that the function be fulfilled optimally in one location, since in a deliberative system the same function may be distributed across various subsystems (Ibidem, p. 5).

In other terms, it's not because the political discussion takes place out of the public eye that the different institutions and actors of the deliberative system are not able to debate about - or control - the content and stakes of the decision to come. As envisaged above, a closed-door deliberation doesn't prevent the actors of the civil society from nourishing the public debate and allowing the deliberation to fulfill its different possible functions. Chambers wrote that "the democratic function of publicity - are policies in the public interest? - can be achieved in secret via a thought experiment but the Socratic function of publicity - are policies based on the best possible reasons? - often cannot" (Chambers, 2004, p. 407)." The sovereign can seek advice from the public - and even ask to the public whether secrecy is desirable or not - without disclosing the content of the political discussion.

If we can admit that perfect communication would guarantee both a perfect deliberation and the conditions of the hypothetical test of publicity, we must concede that such a transparency is out of reach. First, epistemically weak 
conceptions (I and the extended version of II) of deliberation could oppose the conceptions B and C of publicity. Second, the two practical (A and B) conceptions of publicity could oppose the two epistemically strong (the classical version of II as well as III) conceptions of deliberation. Third, epistemically weak and strong conceptions of deliberation could oppose each other respectively. And fourth, weak and strong conceptions of publicity could oppose each other. Consequently, defending an epistemically demanding conception of deliberation can lead to preferring the hypothetical conception of publicity (C) to the practical conceptions of publicity (A and B), and to disentangle the existence of a collective background for the justification of public discussion (see B) from a systemic requirement of public information (A). Even in a democratic system, there are thus some strong epistemic reasons to prefer a closed-door deliberation to a public deliberation as long as the autonomy of the civil society and the possibility of an ex post control of the decision are guaranteed within this system.

\section{Third Part: When Do We Have To Accept Or Reject Political Publicity?}

Notwithstanding the arguments mentioned above, we think that there are some valid reasons to prefer publicity rather than a closed-door deliberation. My first argument against closed-doors deliberation is both internal and descriptive: it contests that secrecy would further the deliberative process better than a public discussion. My second argument is both external and axiological, and contests the status and definition given of the deliberative ideal.

\subsection{The Regressive Argument.}

A variety of reasons lead to think that closed-door deliberation presents worse inconveniences than publicity; that it reproduces them at least; and that the balance between these two conceptions of political visibility cannot be established with certainty anyways.

Assuming that deliberation diminishes the public pressure on the negotiating actors relies on the idea that the level of public pressure is related to the presence of the public eye. We think this idea conflates the practical concept of publicity, which designates the public access to information, with the concept 
of accountability, which covers the idea that the political representatives are politically - and sometimes legally - liable. It is not because a discussion is not public that its parties are not legally or politically accountable. In this framework, the public pressure on the representatives could be even heavier than in the framework of a public debate, insofar as many relevant elements have been knowingly hidden from the public, and citizens can assume that these elements were hidden precisely because their disclosure could have influenced the parties' behaviors. In this context, the parties are tempted to anticipate what will be the pressure of the public spotlight once they will have to disclose the final result of the negotiations. It is all but certain that late disclosure would diminish the level of public pressure on the negotiators.

We could object to this argument that closed-door deliberation still gives the negotiators more autonomy to debate in a dispassionate way, explore new arguments, put forward general interests rather than partisan arguments. In reality, the conception of secrecy defended by supporters of closed-door deliberation is no less naïve and abstract than the conception of publicity they pretend to highlight. The reason why publicity yields negative effects on the deliberation is linked to the fact that the epistemic ideal would be total transparency, that the mere fact people choose to deliberate proves that such a transparency is a mirage, and that the second epistemic/deliberative best paradoxically becomes the figure of the closed-doors deliberation. Nonetheless, the reason why closed-door deliberation is supposed to prevail also relies on the problematic assumption that total opacity is possible. In reality, such opacity never exists: among many others, the case of the Belgian sixth State Reform illustrates how the information constantly flows from the negotiation table to the public (twitter, negotiators' entry speeches, leaks...) and from the public to the negotiation table (boards of the party, civil society...). ${ }^{8}$ The leaked information is important enough to grasp the public's attention but not complete enough to ensure trust between the public and the political space.

8 Going to the point that some of the negotiation documents distributed to the negotiators were each given a slightly different presentation (spelling mistake, words missing...) in order to give the possibility to recognize the source of the leaks to the media. 
Besides, all the epistemic arguments used against publicity can be reproduced in the negotiation space. For Elster a secret discussion favors negotiation more than deliberation insofar as it is easier to negotiate on strategic arguments rather than deliberating on general interest positions (Elster, 1995). It doesn't mean that closed-door discussion does not give any space for public interests or reasonable arguments. But there is no reason to think that the "frankness and candor" of the closed-door deliberation serve a deliberative dynamic rather than unaccountable arguments. The progression toward a common agreement is all but the same as the progression toward a common good. The fact that the "civilizing force of hypocrisy" may be counterproductive does not mean that a closed-door deliberation would be comparatively more civilized. The negotiators may decide to concede a point by pure weariness, or link their consent to the short-term gain they would take from the proposed reform - a punctual financial advantage for the competent executive in the framework of a global reform of the social security system, an electoral advantage due to reframing the electoral districts. It is possible to contest the nature of the common good summoned through the public debate, but it is impossible to control to what extent this common good is even discussed during a closed-door deliberation.

We could object again that a closed-door deliberation is never totally secret. There is an informal dialogue between the organized civil society and the representatives in charge of the political discussion. Moreover, the negotiation field constitutes a social sphere in itself. Taking again the example of the Belgian sixth reform, the negotiating parties were part of a collective story, which pushed them into a relationship of mutual trust. The discussion is an ongoing process that accumulates partial negotiation drafts, intermediate arguments, and informal discussion clauses. The parties are often constrained to negotiate in a specific physical space - the Belgian Senate, the Cabinet of the Minister of Social Affairs... - eat together, are stuck in the same room until the late hours of the night. The negotiation sphere ends up forming a micro deliberative system in itself, where the collective narrative and the individual social capital of the negotiators play a determining role. It is even difficult to step out of this collective narrative that it supposedly agreed by all the parties. It is thus highly difficult for a negotiator to put forward an openly destructive position, a pure personal interest argument, or a totally eccentric proposal. 
In reality, the existence and legitimization of such a micro deliberative system helps to understand why the "frankness and candor" argument and the "civilizing force of hypocrisy" are so reversible in the framework of closed-doors deliberation. Indeed, it is far from certain that closed-door deliberation allows the parties to explore new arguments or test audacious ideas out of the public spotlight. The pressure within the negotiation field is as heavy as it would be in front of the public, it engages the political and social capital of each participant. The bargaining power of the negotiators depends on their social resources amongst the other parties. The success of an argument also depends on the way it is presented, the way it fits the narrative of the negotiation, its common linguistic codes, informal devices... There are thus some arguments that just cannot be defended because they do not fit this common narrative. Closed-doors deliberation creates thus an "enjailment effect" that inhibits the negotiators' creativity, and generates its own endogamous rhetorical biases. As for the Belgian case for instance, four of the eight political parties (the French-speaking and Dutch-speaking ecologist parties as well as the French-speaking and Dutchspeaking liberal parties) originally pled for the creation of a federal electoral district at the level of the whole constituency, allowing thus translinguistic electoral debate for ten to twenty-five percent of the elected federal representatives. This position had been abundantly discussed in the newspapers, and never explicitly rejected by the other four political parties around the table. Nonetheless, the idea turned out to be progressively excluded from the negotiations field - and even ridiculed - without even having been discussed by the partners: the negotiators endowed with the largest social capital constantly dismissed the point from the negotiation agenda; the single world "twenty-seven" (referring to the amount of new-elected nationalist Flemish representatives) pronounced by a negotiator was enough to rule out the point before any single discussion about it; and the expression "my party wants..." by the supporters of the electoral district served as a clear signal that their official support for the measure would not correspond to their effective strategy around the negotiation table. Frankness doesn't mean sincerity and candor does not apply for audacity: the reason why the civilizing force of hypocrisy can lead to conformism or plebiscitary rhetoric are exactly the same why the micro society composing the 
negotiation field is far from guaranteeing the conditions of a reasonable discussion.

The arguments raised for defending secrecy can be reversed so that they bring us to criticize it on the exact same base: besides, closed-door deliberation has to face specific objections regarding its epistemic perspectives. It does not mean that publicity is preferable from an epistemic point of view, but (a) we can think that closed-doors deliberation is not necessarily more rational than public deliberation, and (b) that the comparison between these two configurations can hardly be determined.

In this context, a good reason left to justify closed-doors deliberation is the necessity to find an agreement and give a conclusion to the deliberation. Even if the internal narrative imposed to the negotiation field comes to undermine the conditions of deliberation, it also contributes to aggregate the different available positions: a contrario, and all epistemic consequences aside, we do not contest that public pressure hinders mutual concessions and the progression to a collective agreement. Justified or not, it is interesting to note however that the consensus argument is no longer related to any epistemic or deliberative argument. A reasoned discussion does not necessarily lead to a common agreement, and a collective agreement does not necessarily lead of course to a reasoned discussion. The possible justification of closed-door deliberation would be thus independent from its reasonable/deliberative nature.

\subsection{The Indeterminacy Argument}

The defense of secrecy relies upon the assumption that the definition of 'rational deliberation' is known and shared by everybody. Claiming that closeddoor discussion is best presupposes that we all know and agree on what a reasoned - and more fundamentally, what a legitimate - decision is. But if it is the case, why should we keep the deliberation secret? And even if a common shared conception of deliberation does not entail a collective practice, is this conception really shared? Who decides such a conception is justified to defend either publicity or closed-door deliberation?

Assuming we live in a pluralist society, we must expect that the arguments and procedures that the negotiators take as important might not be the 
arguments that the observers take as important, whether it be at a normative or factual point of view. In this framework the arguments and procedures that the negotiators take as important might not be the arguments that they communicate to the observers as important. It means that the observers are likely to disagree, at least partly, with the positions and procedures discussed within the space of political decision. This is precisely the reason why the content of the discussion must remain concealed to the public. It means moreover, that the observers are not supposed to know when and why such a disagreement occurs.

In this context, it may be hasty to conclude that closed-door deliberation is compatible with an open debate. The asymmetry between the information available to the negotiation and the information available to the observers affects the terms of the discussion taking place within the general public space. Such an asymmetry could affect the terms of the public debate. The normative arguments discussed in the public space do not necessarily align with those that are debated in closed-door deliberation (the public space debating for instance the terms of a possible federal district even though the question is practically precluded from the negotiation field). The factual elements of the closed-door deliberation remain hidden from the public eye as well, leading the public opinion to debate on the basis of erroneous or irrelevant data. The possible obstacles and threats to the negotiation are subject to an analysis gap between the public opinion and the negotiation sphere: as experienced during the preliminary phase of the Belgian sixth State Reform, for instance, the atmosphere between the negotiators was never better than when it was described as 'terrible' by the mass media (and the other way round). Finally, those asymmetries of information nurture themselves insofar as the observers could not even know the relevant information to discuss and assess the decision-making process. The observer does not know what influences or controls the political discussion.

Consequently, the informational asymmetry between the public space and the negotiation sphere can of course pervert the terms of the secret deliberation. The way imperfectly informed arguments influence public debate is likely to orient on its turn the terms of the secret negotiation. In this context, the (real) pressure exerted on the negotiating parties can be based on (wrong) rumors and assumptions - as well as the corresponding threats and demands - emerging 
from the public space: the negotiators even make up to leak partial or even incorrect information in order to influence the power balance of the internal negotiating agenda.

But above all, those asymmetries end up reinforcing the belief according to which only the negotiators are able to deal with the political issues that are submitted to them, and choose whether or not it would be rational/strategic/legitimate to disclose the political information. In this framework, the argument against publicity is a new formulation of liberal elitism. The information gap is justified by the fact that the negotiators supposedly know better than the public and it is neither possible nor necessary to bring the expertise level of the public and the political space up to par. The deliberative argument against publicity precludes thus the very possibility of a "deliberative system" (Mansbridge et al., 2012) at the level of the common public space. Besides, it preempts the definition of what is a rational decision-making process. In a closed-door deliberation, the negotiators not only presuppose that a secret deliberation is better than public deliberation; that the search for the highest possible epistemic input within a small set of deciders is preferable to the search for a higher epistemic input within the public space; that the conditions of deliberation in the framework of a closed-door deliberation are preferable to the conditions of deliberation within a public deliberation; and that the deliberative second best is thus a closed doors-deliberation whose result will be later controlled by the public opinion. They assume that the observers do not need to have the possibility to access, discuss, and assess the terms of this definition. They also take for granted that a discussion on the conditions of desirability - and by extension, the practical implementation - of the deliberation does not need any deliberation. Staging themselves as an epistemic open process of rational justification of the collective decision, the deliberative defense does not take into account the fact that there can be a reasonable disagreement on what a deliberative second best is, and whether it is desirable or not and even whether deliberation must be the ultimate criterion for assessing the legitimacy of a political decision. The observers cannot debate the conditions underlying their exclusion from the political decision. 
The justification of publicity does not rely on its epistemic positive effects on deliberation, but on the fact that the assessment and definition of these positive effects cannot be left to the negotiating parties. Public deliberation is preferable to closed-door deliberation if and when it increases the available information on the different interests at stake, and because it allows staging a broader variety of common good perspectives (Christiano, 1997, p. 260).

In this context, the only reason left for justifying closed-door deliberation would consist in admitting that some people have more legitimacy than others to define the public interest or what a true deliberation should consist of. As underscored by Chambers or Thompson, such an assumption can be debated at the occasion of a collective democratic debate defining the legitimate conditions of secrecy, or at the occasion of an ex-post assessment of the negotiation process: secrecy would be thus legitimate if it receives a deliberated assent. Unfortunately, the secrecy of the negotiation field creates its own acoustic room. As envisaged supra, the observers do not have the possibility to assess whether these predefined conditions are effectively respected and can never be sure how and where to orient their spotlight in the ex-post assessment phase. The negotiators keep the upper hand on the interpretation of what a reasoned discussion is and the definition of the legitimate sphere of secrecy.

\section{Conclusion}

We may admit that political publicity can produce negative effects on the quality of the political discussion. We cannot be sure, however, that these negative effects are more certain and severe than those of a closed-doors deliberation. We have showed why closed-door deliberation could not be accepted by a reasonable citizen and why the principle of political publicity is justified despite its possible negative effects on the quality of the deliberation.

This paper leads us then to two concluding points, the first of which relates to the status of publicity. As envisaged in this paper, political publicity is both an obstacle and a necessary factor for deliberation. On the one hand, publicity stages inescapably diverging conceptions of political discussion. The mere coexistence of more or less self-interested, activist, agonistic conceptions of political 
discussion makes a true deliberation impossible, as the principle itself is subject to a practical disagreement. If there is no congruence between the practical principle of political publicity and that of formal publicity (required by the rational motivation of the practical decision), it is not because this practical principle of publicity cannot ensure the conditions of communication thanks to which this requirement is conceived but because there is no consensus on these conditions. On the other hand, publicity allows for the recognition of deliberation as a "publicly significant" theme (Habermas, 1992) which can be submitted subsequently to a collective discussion, judgment or agreement.

The second point relates then to the way the case for publicity helps to reshape the question of political legitimacy. Secrecy does not allow treating the different possible conceptions of deliberation - and by extension, the different possible deliberative second best patterns - on an impartial ground. Reversely, publicity must not be defended because it ensures a higher deliberative quality but because it is contextually impossible to anticipate what constitutes a rational decision. The discussion on the conditions of the discussion must remain equally open to discussion, as doing otherwise would be contrary to the procedural conditions of political equality. Publicity must be supported because there is no reason to give the negotiating parties a discriminating prerogative to define, assess and control what should be a rational decision. Deliberative theories of democracy assume that the participation and argumentation conditions of the deliberation are to be mutually supportive. In the case they are not, this paper shows that deliberation is at best an instrumental way to ensure political equality. In this sense, closed-doors deliberation must be rejected because it undermines the conditions of political equality within the public space.

Finally, the ultimate criterion for justifying - or not justifying - publicity may be not its deliberative appeal but the way it fosters political equality. If closed-doors deliberation has to be rejected when it opposes a general principle of political equality, it could be equally supported if compatible with a fair deliberative system. Assuming it is impossible to offer an a priori practical hierarchy between the different available conceptions of the political discussion, secrecy might then be justified if it gives the actors the right and means to choose what they think is the most accurate discursive way to defend (build alliances, 
conceive policies, organize common communication) their political preferences - as long as these tools don't harm other people's equal political rights. This point deserves to be developed further.

\section{References}

Benhabib, Seyla (ed.) (1996). Democracy and Difference: Contesting the Boundaries of the Political. Princeton: Princeton University Press.

Blondiaux, Loïc, \& Sintomer, Yves (2002). L’impératif délibératif , Politix, $57,17-37$.

Bohman, James (1996). Public Deliberation. Pluralism, Complexity and Democracy. Cambridge, Mass: MIT.

Bok, Sissela (1982). On the Ethics of Concealment and Revelation. New York: Pantheon.

Chambers, Simone (2004). Behind Closed Doors: Publicity, Secrecy, and the Quality of Deliberation. Journal of Political Philosophy, 12(3): 389-410.

Christiano, Thomas (1996). The Rule of the Many. Boulder: Westview Press.

Christiano, Thomas (1997). The Significance of Public Deliberation. In James Bohman \& William Rehg (eds.), Deliberative Democracy; Essays on Reason and Politics (pp. 243-278). Cambridge, Mass.: MIT Press.

Cohen, Joshua (1986). An Epistemic Conception of Democracy. Ethics, 97(1): 26-38.

Cohen, Joshua (1989). Deliberation and Democratic Legitimacy. In Alan Hamlin \& Philip Pettit, The Good Polity: Analysis of the State (pp. 342-360). New York: Blackwell.

Cohen, Joshua (1996). Procedure and Substance in Deliberative Democracy. In Benhabib, Seyla (ed.). Democracy and Difference: Contesting the boundaries of the Political (pp. 95-119). Princeton: Princeton University Press.

Elster, Jon (1994). Argumenter et négocier dans deux assemblées constituantes. Revue française de science politique, 44(2): 187-256. 
Elster, Jon (1995). Strategic Uses of Argument. In Kenneth Arrow et al. (eds.), Barriers to Conflict Resolution (pp. 236-257). New York: Norton.

Elster, John (1997). The Market and the Forum: Three Varieties of Political Theory. In James Bohman \& William Rehg (eds.) Deliberative Democracy: Essays on Reason and Politics (pp. 3-33). Cambridge, Mass.: MIT Press.

Elster, Jon (1998). Deliberation and Constitution Making. In Jon Elster (ed.), Deliberative Democracy (pp. 97-122). Cambridge: Cambridge University Press.

Estlund, David (2006). Beyond Fairness and Deliberation: the Epistemic Dimension of Democratic Authority. In Thomas Christiano (ed.), Philosophy and Democracy (pp. 69-95), New York: Oxford University Press.

Estlund, David (2002). Political Quality. In David Estlund (ed.), Democracy (pp. 173-234). Malden and Oxford: Blackwell.

Estlund, David (2003). Beyond Fairness and Deliberation. In Thomas Christiano (ed.), Philosophy and Democracy (pp. 69-95). New York: Oxford University Press.

Estlund, David (2009). Democratic Authority: A Philosophical Framework. Princeton: Princeton University Press.

Evans, Phillip \& Wurster, Tom (1997). Strategy and the New Economics of Information, Harvard Business Review, 75(5): 71-82.

Fenster, Mark (2006). The Opacity of Transparency. Iowa Law Review, 91(3): 885-949.

Fung, Archon (2003). Recipes for Public Spheres. Eight Institutional Design Choices and Their Consequences. The Journal of Political Philosophy, 11(3): 338367

Goodin, Robert (1992). Motivating Political Morality. Cambridge, Mass. and Oxford: Blackwell.

Gosseries, Axel (2005). Publicity. In Stanford Encyclopedia of Philosophy. Retrieved from: http://plato.stanford.edu/entries/publicity/. 
Gutmann, Amy \&Thompson, D. (1996). Democracy and Disagreement. Harvard: Harvard University Press.

Gutmann, Amy \& Thompson, D. (1999). Deliberative Politics: Essays on Democracy and Disagreement. Oxford: Oxford University Press.

Habermas, Jürgen (1986). The Theory of Communicative Action. Cambridge, Mass: MIT Press.

Habermas, Jürgen (1990). Moral Consciousness and Communicative Action. Cambridge: MIT Press.

Habermas, Jürgen (1998). Between Facts and Norms: Contributions to a Discourse Theory of Law and Democracy. Cambridge, Mass.: MIT Press.

Hahn, Robert (2002). The False Promise of Full Disclosure'. Policy Review, 115 (October / November).

Hsee, Christopher \& Hastie, Reid (2006). Decision and Experience: Why Don't We Choose What Makes Us Happy?. Trends in Cognitive Sciences, 10(1) 31-37.

Jamieson, Kathleen Hall \& Cappella, Joseph (2008). Echo Chamber: Rush Limbaugh and the Conservative Media Establishment. Oxford: Oxford University Press.

Kant, Immanuel (1970/1795). Perpetual Peace. In Hans Reiss (ed.), Kant's Political Writings (pp. 93-130). Cambridge: Cambridge University Press.

Kerr, Norbert \& MacCoun, Robert (1985). The Effects of Jury Size and Polling Method on the Process and Product of Jury Deliberation. Journal of Personality and Social Psychology, 48(2): 349-363.

Kerr, Norbert \& MacCoun, Robert (2004). Group Performance and Decision-Making. Annual Review of Psychology, 55: 623-655.

Krebs, Valdis (n.d.). Divided We Stand. Retrieved from: http://www.orgnet.com/divided.html. 
Luban, David (1996). The Publicity Principle. In Robert Goodin (ed.), The Theory of Institutional Design (pp. 154-198). Cambridge: Cambridge University Press.

Manin, Bernard (1996). Principes du gouvernement représentatif. Paris: Flammarion.

Mansbridge, Jane (2006). Conflicts and Self-interest in Deliberation. In Samantha Besson \& Jose Luis Marti (eds.), Deliberative Democracy and Its Discontents (pp. 107-132). Burlington: Ashgate Publishing.

Mansbridge, Jane, Bohman, James, Chambers, Simone, Christiano, Thomas, Fund, Archon, Parkinson, John, Thompson, Dennis \& Warren, Michael (2012). A Systemic Approach to Deliberative Democracy. In John Parkinson \& Jane Mansbridge (eds.), Deliberative Systems (pp.1-26). Cambridge: Cambridge University Press.

MacCoun, Robert (2006). Psychological Constraints on Transparency in Legal and Government Decision Making. Swiss Political Science Review, 12(3): 123-133.

Meade Ellen \& Stasavage, David (2008). Publicity of Debate and the Incentive to Dissent: Evidence from the US Federal Reserve. The Economic Journal, 118(528): 695-717.

Mill, John Stuart (1859), On Liberty. Considerations on Representative Government, Cambridge, Cambridge University Press, 2005.

Pestiau, Jean (2001). Mondialisation et bricolage démocratique. In Mondialisation: perspectives philosophiques: Actes du colloque Philosophie et mondialisation tenu à l'Université du Québec à Trois-Rivières les 23 et 24 févr. 2001 (pp. 35-49). Paris: L'Harmattan.

Pitseys, John (2011). Un huis-clos particratique de plus en plus antidémocratique. La revue Nouvelle, 9: 50-59.

Rawls, John (1993). Political Liberalism. New York: Columbia University Press. 
Rottenstreich, Yuval \& Hsee, Christopher (2001). Money, Kisses and Electric Shocks: On the Affective Psychology of Risks. Psychological Science, 12(3): 185-188.

Tversky, Amos \& Kahneman, Daniel (1991). Loss Aversion in Riskless Choice: A Reference-Dependent Model. The Quarterly Journal of Economics, 106(4): 1039-1061.

Williams, Melissa (1995). Justice Toward Groups: Political Not Juridical. Political Theory, 23 (1): 67-91.

Wilson, Thomas (2002). Strangers to Ourselves: Discovering the Adaptive Unconscious. Cambridge, Mass.: Harvard University Press.

Young, Iris Marion (1990). Justice and the Politics of Difference. Princeton: Princeton University Press. 